\title{
Different faces \\ of passion in the context \\ of leadership
}

Rafał Kozłowski, Ph.D. University of Economics In Katowice, Chair In Entrepreneurship

\section{Introduction}

The research on leadership intertwines with many research fields and concentrates on both new ventures, small companies, family firms, as well as big and well-established organisations (Zahra, Covin 1995). They are connected with studies on leadership in such research areas as entrepreneurial vision, social influence, research on risk analysis, uncertainty and ambiguity (Cogliser, Brigham 2004; Daily, McDougall et al. 2002; Vecchio 2003). Therefore, it can be concluded that leadership is one of the most researched topics in literature in the field of management and organization. R. Hogan and R.B. Kaiser (2005) perceive leadership as the most important phenomenon in the humanities. According to R. Hogan and R.B. Kaiser, the leadership research is focused mainly on its positive and constructive aspects, and therefore avoiding the aspect of its dark side. Research on leadership focused on leadership effectiveness, identifying the characteristics of successful leaders, leadership theories and developing leaders. This may be due to the fact that the research has focused primarily on leaders' effectiveness and the factors contributing to optimal results. "that leadership research has primarily focused on leader effectiveness and 
those factors contributing to optimal performance and results (Glaso, Einarsen et al. 2010).

R.P. Vecchio (2003, p. 322) on the basis of literature analysys claims that:

- many of the concepts used in entrepreneurial research can be also found in mainstream of leadeship theory,

- entrepreneurship is leadership in a narrow, specific context,

- the research findings in entrepreneurship should lead to consistent identification of non-linear relationship or inconsistent patterns of results specific to the contex,

- there is a lack of research on "entrepreneurial types".

The overall aim of the paper is to focus on two faces of passion in leadership, the bright and the dark one. Despite the existence of previous work in this field, an integrated view of the relationship between passion and leadership is yet to be made. The paper aims to provide an initial effort of articulation of passion in the context of leadership.

\section{Bright and dark side of passion in leadership}

Although passion is widely described in the management and entrepreneurship literature, the area of research indicating the influence of passion in leadership context is not well explored, although in recent years it has gained both conceptual (Cardon, Sudek, Mitteness 2009a) and empiricalinterest (De Clercq, Honig, Martin 2012; Murnieks, Mosakowski and Cardon 2012). Display of passion increases the likelihood of receiving funds from investors (Chen, Yao, Kotha 2009; Mitteness, Sudek, Cardon 2012). Passion also has a positive impact on the organization's performance (Baum, Locke, Smith 2001; Cardon, Sudek, Mitteness 2009a), and in situations of uncertainty passion ensures consistency of purpose, energy and commitment (Cardon, Sudek, Mitteness 2009a).

R. W. Smilor (1997)suggests that passion is probably the most common phenomenon in the entrepreneurial process. Passion has been identified as an important conceptual variable in the entrepreneurial process. Entrepreneurs are people who are able to discover and exploit new products, processes and new insight (Baum, Locke 2004, p. 588). Entrepreneurial efforts are defined as the ability to recognise and exploit new business opportunities, particularly through the creation of new ventures (Baron 2008; Venkataraman 1997). In the business world, passion is a widespread phenomenon and it is mainly related to positive emotions. J.R. Baum and E.A. Locke (2004, p. 588) call passion for work as love for work, and S. Shane, E.A. Locke, and C.J. Collins (2003, p. 268), 
relate to it as a selfish love of work, while R.W. Smilor (1997, p. 342) defines it as entusiasm, joy or even zeal in unceasing pursuit of valuable, challenging an ambitious purpose.

The research by P.C. Patel, S. Thorgren, and J. Wincent $(2015$, p.219) contributes to a growing body of inquiry exploring passion in the context of leadership. The research so far has shown the differences between passion and other workrelated constructs, individual-level outcomes and general conceptualizations regarding its potential as positive effects. Their study shifts the focus from passion as a one-dimensional conceot to assessing the role of two types of passion and the efficiency of each type of passion in the face of dynamic and complex environmental conditions. Thus, the study explains how under increasing environmental dynamism or environmental complexity project leaders with a specific type of passion may be more successful than others. M.M. Gielnik, D.K. Klemann' and K. Consultancy's (2015) findings suggest that there is substantial variance in entrepreneurial passion over time and changes in entrepreneurial passion are a consequence of entrepreneurs' efforts. Entrepreneurs increase their passion when they make significant progress in their venture and when they invest effort out of their own free choice (Gielnik, Klemann, Consultancy 2015, p. 1027). Among many leadership qualities, passion is essential to mitigate significant challenges and develop novel solutions (Baum, Locke 2004; Baum, Locke, Smith 2001; Cardon, Sudek \& Mitteness 2009a). However, passion could have both positive and negative effects on a business but in the case of passion and its contribution to entrepreneurial culture we expect it to have a positive effect due to the organization's greater ability to be innovative and exploit opportunities.

Passion is a strong indicator of how motivated entrepreneurs are in building a venture, how determined they are in pursuing goals while facing difficulties (Vallerand, Blanchard., Mageau, Koestner, Ratelle, Leonard, Gagne andMarsolais 2003), and it may be a key driver of entrepreneurial action. Therefore, scholars have argued for a deeper understanding of passion as a central element of entrepreneurial efforts (Cardon, Sudek \& Mitteness 2009a; Chen,Yao, Kotha 2009). X.P. Chen, X. Yao and S. Kotha (2009, p. 1999) define entrepreneurial passion as an entrepreneur's intense affective state accompanied by cognitive and behavioral manifestations of high personal value. Entrepreneurial passion refers to consciously accessible intense positive feelings experienced by engagement in entrepreneurial activities associated with roles that are meaningful and salient to the self-identity of the entrepreneur (Cardon, Wincent, Singh, Drnovsek 2009, p. 517). N. Breugst, A. Domurath, 
H. Patzelt and A. Klaukien (2012, p. 172) claim that although leaders might display the same affect, its influence on followers can differ depending on the context. Entrepreneurs led by passion invest higher levels of energy and effort into new ventures (Baum, Locke 2004), they identify themselves with the success and failure of their ventures, and passion combined with vision mobilize energy of followers (Bird 1989). However, M.S. Cardon (2008) claims that the larger the company, the more difficult it is for entrepreneurs to engage in transformational leadership and spread passion among employees.

Leadership requires passion, vision, focus, and the ability to inspire others (Thornberry 2006). Entrepreneurial leadership requires all these, plus a mindset and skill set that helps entrepreneurial leaders identify, develop, and capture new business opportunities. Entrepreneurial leader (and other people), opportunities, actions, resources, competences, organizational architecture and to some extent passion and environment are the controllable components of organizational entrepreneurship that can be assessed, influenced, strengthened or weakened, thereby changing in positive ways to fill the gaps and improve the reconciliation to add new value and wealth creation. This iterative entrepreneurial process gives the unique combination of founders and venture team, opportunity, actions, resources/competences, and context at the particular time and space in the most important success factor of creating or adding value provided for the constituents. The highly dialectical character of organizational entrepreneurship underscores the criticality of leadership reconciling core contradictions and balancing reward and risk, or some likelihood that actual results will differ from expectations (Kozłowski, Bratnicki 2008; Kozłowski, Bratnicki 2007).

The question arises what is the difference between managers, leaders and entrepreneurs. J.A. Schumpeter (1934) distinguishes managers from entrepreneurs in the way that managers control, provide discipline, and order, while entrepreneurs innovate and challenge the balance of the market. According to J.A. Schumpeter entrepreneur's task is to create a new venture and manager's task it to manage the existing company. The distinction made by Schumpeter is similar the distinctions made by other researchers. Administrative functions, or old style strategic management based on coordination, can be opposed to leadership based on vision and entrepreneurial management, which take account of contemporary needs concerning the growth of the organisation. Entrepreneurial management, compared to administrative functions, is more focused on an individual and is forced by the increasing pace of technological development. 
According to M.S. Cardon, C. Zietsma, P. Saparito, B. Matherne and C. Davis (2005) all entrepreneurs may experience passion in a different way, although it must be at the heart of entrepreneurial process. The three domains of entrepreneurial passion are: passion for inventing, passion for founding and passion for developing. Passion for inventing is expressed in scanning the environment for new business opportunities, and developing new products or services. Some entrepreneurs look for new innovative ideas deeper and more frequently than others, and they find the need to provide new solutions to the market extremely motivating. Passion for founding is associated with finding and gathering financial, human and social resources crucial to create a new venture. A new venture creation is an important motivator for many entrepreneurs, and being a founder can be both complex and crucial in regarding oneself as an entrepreneur. The entrepreneurs who experience the passion for founding derive pleasure from the process of creating a new venture and often develop the identities that are intertwined with the identity of a venture. The last domain is the passion for developing and it relates to the growth and expansion of the venture. For many entrepreneurs the growth and development of a venture is even more motivating then the process of creating a venture. And although in many cases entrepreneurs develop a venture they have founded themselves, it is also possible that entrepreneurs who experience passion for developing will demonstrate high levels of passion for existing companies and they will engage in developing valuable and sustainable firms. According to L.H. Haber (2011) entrepreneurship might be regarded as a personality trait, considered as a multifaceted personality, with hubristic motivation enforced by acts of transgression which allow breaking down obstacles and transcending stereotypes existing in various areas of activities. Therefore, entrepreneurs and leaders who passionately found or run companies will experience positive and intensive feelings for their ventures and the role of a founder will be crucial in their consciousness. As a result, a venture created with passion will define their identity and will hold their personal and professional life together.

Recent study of the 100 largest organizational crises has shown that in majority of cases, the failure of successful organizations largely follows the same logic: they grew and changed too quickly (or too slowly), had too powerful (or too weak) leadership, nurtured an excessive (or lack of success) culture (Probst, Raisch 2005). In the extreme cases organizations simply burnout (implode) or have premature aging syndrome (explode). Therefore, the extremes could be negative for the enterprise in the long run (Finkelstein 2003). Despite 
growing evidence showing that extreme, quick, fix solutions are ineffective, entrepreneurs still appear to make this a frequent practice. On the other hand, according to M.M. Gielnik, D.K. Klemann, K. Consultancy (2015, p. 1012), research has shown that it usually takes several years to launch a new firm, during which the entrepreneur has to invest countless hours (Reynolds, Curtin 2008) and considerable effort to successfully start a new venture (Foo, Uy, Baron 2009). That is why, scholars have proposed that, beyond other characteristics such as need for achievement (Rauch, Frese 2007), entrepreneurial passion is an important personal characteristic fuelling entrepreneurial efforts (Baum, Locke, Smith 2001; Cardon, Sudek \& Mitteness 2009a). However, M.F. Kets deVries (1985) implies that the traits that initially allowed the leader to succeed can become a source of destructive internal needs, which may endanger their ventures over time (Haynes, Hitt, and Campbell 2015, p 483). Entrepreneurial leaders' greed and hubris (Haynes, Hitt, and Campbell 2015), confrontation with risk, entrepreneurial stress, and entrepreneurial ego (Kuratko and Hodgetts 2007) can negatively affect successful organizations and constitute the internal dark side of an organization.

\section{Conclusions}

M.S. Cardon, C. Zietsma, P. Saparito, B. Matherne i C. Davis (2005) state that passion is at the heart of entrepreneurship. As M. Brännback,A Carsrud, J. Elfving and N.K Krueger (2006, p. 6), notice, passion can fuel motivation, enhance mental activity, and provide meaning to everyday work. It can foster creativity and the recognition of new information patterns critical to the discovery and exploitation of promising opportunities (Baron 2008). Passion has been associated with entrepreneurs' ability to raise funds from investors (Cardon, Wincent, Singh and Drnovsek 2009b; Mitteness, Sudek, Cardon 2012; Sudek 2006), and to hire and motivate key employees (Cardon 2008). Passion is a strong indicator of how motivated entrepreneurs are in creating a venture, how creative they are when facing problems, and how determined they are in pursuing goals while facing difficulties (Vallerand et al. 2003), and it may be a key driver of entrepreneurial action. Passion may drive the entrepreneurs to overcome difficulties, to come up with new ideas, to act and to be persistent in achieving goals. On the other hand, excessive passion can lead to blind stubbornness, irrational dedication to a venture or even to obsessive behaviour. Therefore, if passion can contribute to creation and growth of a venture, when it is dominated by greed and hubris it can contribute to its failure. 


\section{Summary}

\section{Different faces of passion in the context of leadership}

The paper describes passion, which depending on the context, may motivate entrepreneurial leaders not only to found an organization, but also to grow and expand their ventures. It should also be noted that there is also the dark side of passion dominated by greed and hubris, which may result in counterproductive outcomes.

Key words: leadership, entrepreneurship, passion.

\section{Streszczenie}

\section{Różne oblicza pasji w kontekście przywództwa}

Artykuł zwraca uwagę na pasję, która w zależności od sytuacji, może motywować przedsiębiorczych liderów nie tylko do tworzenia nowych przedsięwzięć, ale także do budowania i rozwijania tych przedsięwzięć. Należy zwrócić uwagę, że jest także ciemna strona pasji, która jest zdominowana przez chciwość i pychę, co może doprowadzić do wyników odmiennych niż oczekiwane.

Stowa

kluczowe: przywództwo, przedsiębiorczość, pasja.

\section{References:}

1. Baum J. R., Locke E. A., Smith K. G. (2001), A multidimensional model of venture growth, "Academy of Management Journal", No. 44, pp. 292-303.

2. Baum J.R., Locke E.A. (2004), The Relationship of Entrepreneurial Traits, Skill, and Motivation to Subsequent Venture Growth," Journal of Applied Psychology", No. 89, pp. 587-598.

3. Baron R. (2008), The role of affect in the entrepreneurial process, "Academy of Management Review", No. 33, pp. 328-340.

4. Bird B. J. (1989) Entrepreneurial behawior, Scott Foresman, Glenview.

5. Brännback M., Carsrud A., Elfving J., Krueger N.K. (2006), Sex, [drugs], and entrepreneurial passion? An exploratory study, paper presented at the Babson College Entrepreneurship Research Conference, Bloomington.

6. Breugst, N., Domurath A., Patzelt H., Klaukien A. (2012), Perceptions of Entrepreneurial Passion and Employees' Commitment to Entrepreneurial Ventures, "Entrepreneurship: Theory and Practice", No. 36, pp. 171-192. 
7. Cardon M.S., Zietsma C., Saparito P., Matherne B., Davis C. (2005), A tale of passion: new insights into entrepreneurship from a parenthood metaphor, "Journal of Business Venturing", No. 20, pp. 23-45.

8. Cardon M.S. (2008) Is passion contagious? The transference of entrepreneurial emotion to employees. "Human Resource Management Review", No. 18, pp. 77-86.

9. Cardon M. S., Gregoire D.A., Stevens Ch. E,Patel P. C. (2013), Measuring entrepreneurial passion: Conceptual foundations and scale validation, "Journal of Business Venturing", No. 28, pp. 373-396.

10. Cardon M.S., Sudek R.,Mitteness C. (2009a), The impact of perceived entrepreneurial passion on angel investing,in: A.L. Zacharakis, (oprac.), Frontiers of Entrepreneurship Research: Proceedings of the Babson College Entrepreneurship Research Conference, nr. 29, Babson College, Wellesley.

11. Cardon M.S., Wincent J., Singh J., Drnovsek M. (2009b), The nature and experience of entrepreneural passion, "Academy of Management Review", No. 34, pp. 511-532.

12. Chen X. P., Yao X., Kotha S. (2009), Entrepreneur passion and preparedness in business plan presentations: A persuasion analysis of venture capitalists' funding decisions, "Academy of Management Journal”, No. 52, pp. 199-214.

13. Cogliser C. C., Brigham K. H. (2004), The intersection of leadership and entrepreneurship: mutual lessons to be learned, "Leadership Quarterly", No. 15, pp. 771-799.

14. Daily C. A., McDougall P. P., Covin J. G.,Dalton D. R. (2002), Governance and strategic lead-ership in entrepreneurial firms, "Journal of Management", No. 28(3), pp. 387-412.

15. De Clercq D., Honig B., Martin B. (2012), The roles of learning orientation and passion for work in the formation of entrepreneurial intention, "International Small Business Journal", No. 31(6), pp. 652-676.

16. Finkelstein S. (2003), Why Smart Executives Fail: And What You Can Learn From Their Mistakes,Portfolio, New York.

17. Foo M.-D., Uy M.A., Baron R.A. (2009), How do feel- ings influence effort? An empirical study of entre- preneurs' affect and venture effort, "The Journal of Applied Psychology", No. 94, pp. 1086-1094.

18. Glaso L., Einarsen S., Mathiesen S. B., \& Skogstad A. (2010), The dark side of leaders: A representative study of interpersonal problems among leaders, "Scandinavian Journal of Organizational Psychology", No. 2(2), pp. 3-14.

19. Gielnik M. M., Klemann D. K.,Consultancy K. (2015), I Put in Effort, Therefore I Am Passionate": Investigating the Path From Effort To Passion in Entrepreneurship, "Academy of Management Journal”, No. 58 (4), pp. $1012-1031$.

20. Haber L.H. (2011), Przedsiębiorczość w zarządzaniu [in:] L. H. Haber (ed.), Komunikowanie i zarządzanie w społeczeństwie informacyjnym, NOMOS, Kraków, pp. 226-251. 
21. Harrison R., Leitch C., McAdam M. (2015), Breaking Glass: Toward a Gendered Analysis of Entrepreneurial Leadership, "Journal of Small Business Management", No. 53 (3), pp. 693-713.

22. Haynes K., Hitt M. A.,Campbell J. (2015), The Dark Side of Leadership: Towards a Mid-Range Theory of Hubris and Greed in Entrepreneurial Contexts, "Journal of Management Studies”, No. 52 (4), pp. 479-505.

23. Hogan R., Kaiser R. B. (2005), What we know about leadership, "Review of General Psychology", No. 9 (2), pp. 169-180.

24. Kets de Vries M. F. (1985), The dark side of entrepreneurship, "Harvard Business Review", No. 63, pp. 160-182.

25. Kozłowski R., Bratnicki M. (2008), Unbundling the dialectical structure of entrepreneurial leadership, [in:] P. Pachury, R. Lescroart (eds.), Partnership, clusters and networks in knowledge based economy, La Haute Ecole „Blaise Pascal", Aston, pp. 30-39.

26. Kozłowski R., Bratnicki M. (2007), Entrepreneurial leadership: Towards a new framework, [in:] Studying Leadership Conference. Purposes, Politics and Praxis, Warwick Business School, Warwick.

27. Kuratko D. F.Hodgetts R. M. (2007), Entrepreneurship: Theory, Process, Practice, 7 th edition. Mason, Thomson/Southwestern.

28. Mitteness C., Sudek R., Cardon M.S. (2012), Investor characteristics that determine whether perceived passion leads to higher evaluations of funding potential "Journal of Business Venturing", No. 27, pp. 592-606.

29. Murnieks C. Y., Mosakowski E.,Cardon M. S. (2012), Pathways of passion: identity centrality, passion, and behavior among entrepreneurs'. "Journal of Management", No. 40 (6), pp. 1583-1606.

30. Patel P.C., Thorgren S., Wincent J. (2015), Leadership, Passion and Performance: A Study of Job Creation Projects during the Recession, "British Journal of Management", No. 26 (2), pp. 211-224.

31. Probst G., Raisch S. (2005), Organiational Crisis: The Logic of Failure, "Academy of Management Executive", No. 19 (1), pp. 90 -105.

32. Rauch A., Frese M. (2007), Let's put the person back into entrepreneurship research: A meta-analysis on the relationship between business owners' personality traits, business creation, and success, "European Journal of Work and Organizational Psychology", No. 16, pp. 353-385.

33. Reynolds P. D., Curtin R. T. (2008), Business creation in the United States: Panel study of entrepreneurial dynamics II initial assessment, "Foundations and Trends in Entrepreneurship", No. 4, pp. 155-307.

34. Schumpeter J.A. (1934), The Theory of Economic Development. Harvard University Press, Cambridge.

35. Shane S., Locke E.A., Collins C.J. (2003), Entrepreneurial motivation, „Human Resource Management Review", No. 13, pp. 257-279.

36. Smilor R. W. (1997), Entrepreneurship: Reflections on a subversive activity, "Journal of Business Venturing", No. 12, pp. 341-346. 
37. Sudek R. (2006), Angel investment criteria, "Journal of Small Business Strategy", No. 17, pp. 89-103.

38. Thornberry N. (2006), Lead like an Entrepreneur: Keeping the Entrepreneurial Spirit Alive within the Corporation, McGraw-Hill, New York.

39. Vaughan D. (1999), The dark side of organizations: mistake, misconduct, and disaster, "Annual Review of Sociology", No. 25, pp. 271-305.

40. Vallerand R. J., Blanchard C., Mageau G. A., Koestner R., Ratelle C., Leonard M., Gagne M., Marsolais J. (2003), Les passions de l'ame: On obsessive and harmonious passion, "Journal of Personality and Social Psychology", No. 85, pp. 756-767.

41. Vecchio R. P. (2003), Entrepreneurship and leadership: common trends and common threads, "Human Resource Management Review", No. 13(2), pp. 303-327.

42. Venkataraman S. (1997), The distinctive domain of entrepreneurship research: An editor's perspective, [in:] J. Katz, R. Brockhaus (eds.), Advances in entrepreneurship, firm emergence, and growth, No. 3, JAI Press,Greenwich, pp. 119-138.

43. Zahra S. A.,Covin J. G. (1995), Contextual influences on the corporate entrepreneurship- performance relationship: a longitudinal analysis, "Journal of Business Venturing", No. 10 (1), pp. 43-58. 